Crop Breeding and Applied Biotechnology 14: 166-173, 2014

Brazilian Society of Plant Breeding. Printed in Brazil

\title{
ARTICLE
}

http://dx.doi.org/10.1590/1984-70332014 v14n3a25

\section{Genetic diversity and structure of Astrocaryum jauari (Mart.) palm in two Amazon river basins}

Liliane D. Santos Oliveira ${ }^{1}$, Santiago L. Ferreyra Ramos ${ }^{2}$, Maria T. Gomes Lopes ${ }^{1 *}$, Gabriel Dequigiovanni ${ }^{2}$, Elizabeth Ann Veasey ${ }^{2}$, Jeferson L. Vasconcelos de Macêdo ${ }^{3}$, Jacqueline S. Batista ${ }^{4}$, Kyara M. Formiga ${ }^{4}$ and Ricardo Lopes ${ }^{3}$

Received 17 December 2013

Accepted 14 April 2014

\begin{abstract}
Astrocaryum jauari is a non-domesticated palm that is exploited by poachers. Our objective was to investigate the organization of the genetic diversity and structure of three A. jauari populations. The study was carried out in the state of Amazonas, between the municipalities of Coari and Manaus. Nine microsatellite loci were used for the genetic analyses. High genetic variation was found, with a mean number of alleles per locus varying from 3.9 to 4.4. The average observed heterozygosity, varying from 0.71 to 0.78 , was higher than expected. No spatial genetic structure was detected, since only one cluster was observed. Our results indicate a possible dispersion strategy and suggest that conservation measures of this species should focus mainly on the populations found at the end of the main river (Solimões) where most of the plant material originating from the headwaters of the tributaries of this river is concentrated.
\end{abstract}

Key words: Amazonia, rivers Solimões and Urucu, Jauari, palm domestication.

\section{INTRODUCTION}

Astrocaryum jauari Mart. is an Amazonian palm of the Arecaceae family, adapted to seasonal oscillations in river levels (Kahn and Millán 1992) that involve a flood phase where water covers the plains on the margins of the river and a dry phase after the water recedes. These plains are therefore referred to as floodplain forests (whitewater-inundated forests are known as várzeas and blackwater-inundated forests as igapós) (Sioli 1984, Kahn and Millán 1992). It is important to mention that the water color is mainly given by the place of origin and by the sediments that contribute to each of them. White water rivers have their source in the Andes mountain range and contain considerable amounts of suspended clay, while black waters originate from the forest and are darkened by colloidal humic particles from decomposing organic matter (litter) (Sioli 1984). These seasonal floodings have led to the adaptation of $A$. jauar and other species to ensure survival when partially or totally submersed during those phases (Piedade et al. 2006). The distribution of $A$. jauari and other plants adapted to this habitat varies according to flooding regimes and seasonal- ity, precipitation patterns around the hydrographic basins and due to evolutionary geographical events, defined by the effect of sediment deposition and erosion on changes in river courses (Albernaz et al. 2012).

A. jauari is found in the Amazon regions of Colombia, Venezuela, French Guiana, Guiana, Suriname, Ecuador, Peru, and Brazil (Kahn 2008). In Brazil, it occurs in the states of Pará, Acre, Roraima, and Amazonas (Kahn and Millán 1992). This species is traditionally used by the people of different native Amazonian communities as a source of food, fiber and shelter (Zambrana et al. 2007), and until 1998 is also constituted the basis of industrial heart-of-palm production in Central Amazonia (Piedade et al. 2003). Furthermore, the fruit of this species is a food source for a variety of fish, especially of the Characidae family. This family comprises the two most important fish species in terms of local consumption and exportation: Piaractus brachypomus Cuvier (Pirapitinga) and Colossoma macropomum Cuvier (Tambaqui). This suggests a co-evolutionary symbiosis between $A$. jauari and these fish species that feed on the palm fruits and help disperse the

\footnotetext{
${ }^{1}$ Universidade Federal do Amazonas (UFAM), Faculdade de Ciências Agrárias, 60.077-000, Manaus, AM, Brazil

${ }^{2}$ Universidade de São Paulo (USP), Escola Superior de Agricultura “Luiz de Queiroz" (ESALQ), Departamento de Genética, CP 83, 13.400-970, Piracicaba, SP, Brazil

${ }^{3}$ Embrapa Amazônia Ocidental, AM 010, CP 319, 69.048-660, Manaus, AM, Brazil

${ }^{4}$ Instituto Nacional de Pesquisas da Amazônia (INPA), Laboratório Temático de Biologia Molecular, Laboratório de Fisiologia Comportamental, Coordenação de Biodiversidade, CP 478, 69.060-001, Manaus, AM, Brazil.*E-mail: mtglopes@ufam.edu.br
} 
seeds (Piedade et al. 2006).

A. jauari is one of the many species of Amazonia about which no information on phenological, agronomic or genetic aspects is available. Knowledge about the diversity and genetic structure of natural $A$. jauari populations is an important initial step towards the species' conservation and management to initiate a domestication process. It is worth emphasizing that this species is one of the alternatives that could lead to improvements in the life quality of river populations. For being considered highly important for both mankind and the surrounding fauna and for playing a vital role in the development of local communities, the conservation, management and exploitation of this resource are extremely important.

Similarly to other plant species adapted to the conditions of the floodplains of the Urucu and Solimões rivers, A. jauari occurs in the municipality of Coari in Amazonas where the corporation Petróleo Brasileiro S.A. (Petrobrás) explores oil and natural gas fields. All crude oil produced by the company is transported by river across these hydrographic basins and the gas through a pipeline that consists of two $280 \mathrm{~km}$ tubes, beginning in Coari at the River Urucu and ending in Manaus, the state capital (Frota et al. 2010). The area of influence of this company includes floodplains (both várzeas and igapós), dry land and rivers, i.e., unforeseen events could affect the vegetative biodiversity of the area (Frota et al. 2010).

In addition, the Amazon rainforest has an annual average temperature of $23.5^{\circ} \mathrm{C}$, annual rainfall of $2464 \mathrm{~mm}$ and evapotranspiration of $1657 \mathrm{~mm}$ (Shukla et al. 1990). However, the Brazilian Amazon has been affected by extreme climatic events in terms of rainfall over the past decade, resulting in drought (and consequent temperature increases) and flooding of rivers. This could be related to the phenomena El Niño and La Niña, which influence the sea surface temperature in the Pacific. Considering the hydrological regime, the Amazon region seems to be affected by events in the Atlantic and Pacific oceans. Changes in the sea surface temperature cause changes in atmospheric dynamics. The variability of atmospheric dynamics induces new settings in the patterns of rainfall and flow in the Amazon Basin (Sena et al. 2012). Therefore, given the lack of knowledge regarding the diversity and genetic structure of this species and on how to protect it against climatic and man-made events, the objective of this study was to evaluate natural A.jauari populations in the hydrographic basins of the Urucu and Solimões rivers using heterologous microsatellite markers developed for Astrocaryum aculeatum G. Mey. Considering that the species under study has not been domesticated yet, one of the goals of this study was to generate information on the organization of the genetic diversity and structure of three natural populations of $A$. jauari, which is indispensable for the management, use and conservation of the genetic resources of this species.

\section{MATERIAL AND METHODS}

\section{Study area and plant sampling}

The study was conducted in the State of Amazonas between the municipalities of Coari and Manaus. The species A. jauari is distributed along the margins of both white and blackwater rivers of the region (Schluter et al. 1993). Therefore, we sought to sample plants from natural populations from different communities along the hydrographic basins of the Urucu and Solimões rivers, considered to be black and whitewater rivers, respectively (Sioli 1984), and situated within the influence area of the Coari-Manaus gas pipeline. Samples were taken from three populations: one from the community Santa Luzia do Buiuçuzinho situated on the River Urucu, and two from the communities Matrinxã and Nossa Senhora das Graças on the Solimões River; Matrinxã lies between the other two communities (Figure 1A).

The large distances between these communities and the location of each one in the hydrographic basins of the Urucu and Solimões rivers were decisive factors in the selection of the sampling locations. The community Santa Luzia do Buiuçuzinho (lat 04 11' 59.9" S, long 63 42'33" $\mathrm{W})$ belongs to the municipal district of Coari and lies near Lake Coari. This community, founded in 1990, consists of around 35 families and is situated on a dry land area. The community Matrinxã (lat $03^{\circ} 46^{\prime} 44^{\prime \prime}$ S, long $62^{\circ} 21^{\prime} 54^{\prime \prime}$ W) belongs to the municipality of Codajás situated on the River Solimões and is close to the point where this river meets the River Urucu. It is considered to be a relatively small community with only seven families. The community Nossa Senhora das Graças (lat 03 20'37' S, long 60³5' $34^{\prime \prime} \mathrm{W}$ ) is located on the right margin of the River Solimões in a floodplain within the municipality of Manacapuru. It is inhabited by 65 families whose main source of both subsistence and income is fishing and who practice family farming. The two latter communities are located on floodplains (Fraxe et al. 2007). Unrestricted random sampling was carried out in each of the populations selected for the study, identifying 30 plants. One leaflet was collected from each plant, stored in silica gel and stored at $-20^{\circ} \mathrm{C}$ in the Laboratory of Molecular Biology at the National Institute of Amazonian Research (LTBM-INPA).

DNA extraction and genotyping of microsatellites 
DNA was extracted according to the method described by Doyle and Doyle (1990) and quantified by electrophoresis in agarose gel $(0.8 \% \mathrm{w} / \mathrm{v})$ stained with GelRed ${ }^{\mathrm{TM}}$ (Biotium, Hayward, California, USA). Fourteen microsatellites developed for A. aculeatum (Ramos et al. 2012) were tested. Amplifications by polymerase chain reaction (PCR) were carried out in a total volume of $10 \mu \mathrm{L}$, containing $10 \mathrm{ng}$ of genomic DNA, $1 \mathrm{X}$ buffer, $210 \mu \mathrm{M}$ of each dNTP, $1.5 \mathrm{mM}$ $\mathrm{MgCl}_{2}, 0.16 \mu \mathrm{M}$ forward primer and M13 solution (FAM or NED) (Schuelke 2000), $0.32 \mu \mathrm{M}$ reverse primer, and 1.05 U Taq DNA polymerase (Promega, São Paulo, Brazil). The amplification reactions were carried out in two stages: the first consisted of heating to $68^{\circ} \mathrm{C}$ for $2 \mathrm{~min}$ and then $92^{\circ} \mathrm{C}$ for $30 \mathrm{~s}$; followed by 30 denaturation cycles at $92{ }^{\circ} \mathrm{C}$ for $30 \mathrm{~s}$, followed by annealing using specific temperatures for each primer pair (Table 1) for $35 \mathrm{~s}$ and extension at $68^{\circ} \mathrm{C}$ for $35 \mathrm{~s}$. In the second stage, 15 denaturation cycles were carried out at $92{ }^{\circ} \mathrm{C}$ for $20 \mathrm{~s}$, followed by annealing at 53 ${ }^{\circ} \mathrm{C}$ for $30 \mathrm{~s}$ and extension at $72{ }^{\circ} \mathrm{C}$ for $30 \mathrm{~s}$, with a final extension step at $72^{\circ} \mathrm{C}$ for $15 \mathrm{~min}$ followed by $68^{\circ} \mathrm{C}$ for 30 min (Ramos et al. 2012). The samples were amplified using a Veriti Thermal Cycler (Applied Biosystems, Foster City, California, USA). The amplification products were visualized by electrophoresis in $1.5 \%$ agarose gel stained with GelRed (Biotium, Hayward, California, USA). To determine the allele size, the high-quality PCR products were subjected to capillary electrophoresis in an ABI 3130XL Genetic Analyzer (Applied Biosystems, Foster City, California, USA) with a marker containing fragments of known size, ET-550 ROX size standard (GE Healthcare, Amersham, Buckinghamshire, UK). The genotypes were observed and analyzed using the GENEMAPPER v4.0 software program (Applied Biosystems, Foster City, California, USA).

\section{Statistical analysis}

The total number of alleles $(A)$, number of private alleles $\left(A_{P}\right)$, observed heterozygosity $\left(H_{O}\right)$, expected heterozygosity $\left(H_{E}\right)$, inbreeding coefficient $(f)$, and Hardy-Weinberg Equilibrium (HWE) from the exact test and linkage disequilibrium (LD) tests were estimated for each locus and in each individual population using GDA software (Lewis and Zaykin 2002). The presence of null alleles was verified for each primer using MICRO-CHECKER software (Oosterhout et al. 2004) with a confidence interval of $95 \%$ and 10,000 interactions.

In an attempt to verify the existence of a genetic structure or differentiation between the sampled populations, two matrices were calculated using pairwise fixation index $\left(F_{S T}\right)$ values between the populations and between the geographical basins to which they belong. These analyses were obtained by a significance test with 99,999 permutations and adjusting the level of significance with Bonferroni correction (Rice 1989). Wright (1951)'s F statistics were calculated by Weir and Cockerham (1984) algorithms, evaluating the statistical significance based on 20,000 bootstrap replicates. The Mantel test (Smouse et al. 1986) was performed to analyze the correlation between the geographic distances between populations and the linearized genetic distances $\left(F_{S T}\right)$ (Slatkin 1995), and Nei's genetic distances (Nei et al. 1978) among populations. The tests of significance were performed using 100,000 permutations. Pairwise calculations of $F_{S T}$, the linearized $F_{S T}$ matrix and the Mantel test were carried out with Arlequin v.3.5.1.2 software (Excoffier and Lischer 2010). Nei's genetic distances were calculated using GDA software (Lewis and Zaykin 2000) and the geographic distance matrix using the earth.dist function of the Fossil 0.3.7 package from the R project (Vavrek 2011).

Table 1. Genetic diversity parameters determine by microsatellite loci in three Astrocaryum jauari populations in the hydrographic basins of the Urucu and Solimões rivers in the state of Amazonas, Brazil

\begin{tabular}{|c|c|c|c|c|c|c|c|c|c|c|c|c|c|c|c|c|c|}
\hline $\begin{array}{l}\text { SSR } \\
\text { Loci }\end{array}$ & $\begin{array}{c}\boldsymbol{T} \\
\left({ }^{0} \mathrm{C}\right) \\
\end{array}$ & $\begin{array}{c}\text { Allele } \\
\text { range (bp) }\end{array}$ & \multicolumn{5}{|c|}{ Santa Luzia do Buiuçuzinho } & \multicolumn{5}{|c|}{ Nossa Senhora das Graças } & \multicolumn{5}{|c|}{ Matrinxã } \\
\hline $\mathrm{Aac} 03$ & 60 & $146-168$ & 30 & 2 & $0.51 * 3$ & 1.00 & -1.00 & 30 & 2 & $0.48 *$ & 0.77 & -0.61 & 30 & 2 & $0.51 *$ & 1.00 & -1.00 \\
\hline $\mathrm{Aac} 04$ & 60 & $201-239$ & 30 & 6 & 0.75 & 0.77 & -0.02 & 29 & $8(2)$ & 0.80 & 0.90 & -0.12 & 30 & 6 & 0.79 & 0.87 & -0.10 \\
\hline $\mathrm{Aac} 05$ & 62 & $384-420$ & 29 & 3 & 0.45 & 0.59 & -0.32 & 30 & 3 & 0.19 & 0.20 & -0.08 & 30 & 1 & $--^{2}$ & --- & --- \\
\hline Aac06 & 64 & $161-183$ & 29 & $8(1)$ & 0.77 & 0.86 & -0.12 & 30 & 6 & 0.81 & 0.90 & -0.11 & 29 & 7 & 0.73 & 0.90 & -0.23 \\
\hline Aac10 & 60 & $97-133$ & 29 & 2 & $0.47^{*}$ & 0.72 & -0.56 & 30 & $3(1)$ & $0.52 *$ & 0.97 & -0.87 & 29 & 2 & $0.49 *$ & 0.79 & -0.65 \\
\hline Aac12 & 60 & $178-194$ & 27 & 4 & $0.66^{*}$ & 0.96 & -0.47 & 27 & 3 & $0.62 *$ & 1.00 & -0.63 & 29 & 4 & $0.66^{*}$ & 0.90 & -0.36 \\
\hline Aac13 & 60 & $159-207$ & 30 & 3 & $0.59 *$ & 0.90 & -0.53 & 30 & 3 & $0.61 *$ & 0.97 & -0.60 & 30 & 3 & $0.59 *$ & 0.97 & -0.65 \\
\hline Aac14 & 55 & $354-416$ & 28 & $6(1)$ & 0.70 & 0.68 & 0.04 & 30 & $6(1)$ & 0.50 & 0.53 & -0.08 & 30 & $6(1)$ & 0.75 & 0.67 & 0.11 \\
\hline Average & & & & 4.44 & 0.63 & 0.78 & -0.25 & & 4.33 & 0.56 & 0.74 & -0.32 & & 3.89 & 0.58 & 0.71 & -0.22 \\
\hline
\end{tabular}

$N=$ Number of plants; $A=$ Number of alleles per locus, $(\mathrm{Ap})=$ Private alleles; $H_{E}=$ Expected heterozygosity; $H_{\mathrm{o}}=$ Observed heterozygosity; $f=$ Inbreeding coefficient; $T \mathrm{a}$ $=$ Annealing temperature. ${ }^{2}-=$ monomorphic locus. ${ }^{3}$ Deviation from Hardy-Weinberg equilibrium exact test $(P<0.005556$, after standard Bonferroni correction $)$ 
In order to determine the genetic structure of the sampled populations, the number of clusters within the set of accessions evaluated was estimated using the Bayesian analysis with the Structure software (Pritchard et al. 2000). We adopted the Admixture model used for applicability in real populations. The number of clusters $(K)$ was estimated using $\ln \operatorname{Pr}(X / K)$ for different values of $K$ (Pritchard et al. 2000). The number of $K$ was defined from 1 to 8 and 20 interactions were carried out for each $K$ with a burn-in of 100,000 followed by 500,000 Markov Chain Monte Carlo interactions. The degree of clustering or dispersion of genetic diversity between the sampled plants in the three populations was visualized using Principal Coordinates Analysis (PCoA), using GenAlEx 6.5 (Peakall and Smouse 2012).

\section{RESULTS}

\section{Transfer of heterologous primers and genetic diversity indices}

Of the 14 tested microsatellite primers, 12 produced results that were easy to visualize and only two amplified no products (Aac08 and Aac09). These 12 microsatellite primers were optimized for the species under study and then used for genotyping each sampled accession. Three of the 12 primers proved monomorphic and were therefore excluded from the statistical analysis. Among the nine polymorphic loci, the presence of null alleles was only observed in the Matrinxã population at locus Aac07.

The nine loci confirmed the presence of a large content of genetic information with a total of 46 alleles, with 2 to 9 alleles per locus and an average of 5.11. Considering the three populations, the number of alleles per locus varied from 3.9 to 4.4 (Table 1). Loci Aac06 and Aac04 were shown to be the most polymorphic (varying from 6.0 to 8.0 alleles per locus), while the locus with lowest polymorphism was Aac03 (2.0 alleles per locus for the three populations) (Table 1). Eight alleles were classified as private, four of which were observed in Nossa Senhora das Graças, three in Santa Luzia de Buiuçuzinho and one in the Matrinxã population. The expected heterozygosity $\left(H_{E}\right)$ or genetic diversity for the Nossa Senhora das Graças population varied from 0.19 to 0.81 , with an average of 0.56 . For the other two populations, $H_{E}$ varied between 0.45 and 0.79 , with averages of 0.63 for Santa Luzia do Buiuçuzinho population and 0.58 for Matrinxã population. The values for observed heterozygosity $\left(H_{O}\right)$ were higher than $H_{E}$ for most loci, except for $\mathrm{Aac} 07$ and Aac14. The values for $H_{O}$ varied between 0.20 and 1.0, with averages of $0.78,0.74$, and 0.71 for Santa Luzia do Buiuçuzinho, Nossa Senhora das Graças and Matrinxã, respectively. On average, the inbreeding coefficient or fixation indices were negative and significantly different from zero, indicating that high levels of heterozygotes were observed. The analyses also indicated that $\mathrm{HW}$ was not found at loci Aac03, Aac10, Aac12 and Aac13 in any of the three populations, and the same was observed for locus Aac7 in the Matrinxã population. Linkage equilibrium was detected for most of the studied loci, assessed by Fisher's exact test with 20,000 runs, when compared with probabilities equal to or less than 0.00139 after standard Bonferroni correction. The linkage equilibrium of the populations in Buiuçuzinho, Nossa Senhora das Graças and Matrinxã was 88.9\%, 77.8\% and $58.3 \%$, respectively. This result indicates that most loci segregate independently.

\section{Genetic structure}

Pairwise differentiation between all three populations and between the two hydrographic basins indicated significant but low values (Table 2). From Wright's F-statistics (Wright 1951), the observed total inbreeding was $F_{I T}=-0.204$ and intrapopulation inbreeding or inbreeding owing to reproductive systems $\left(F_{I S}=-0.266\right)$ was lower than inbreeding as a result of subdivision $\left(F_{S T}=0.049\right)$, confirming that the diversity is more concentrated within than between populations. The Mantel test using both the genetic matrices of linearized $F_{S T}$ and Nei's genetic distances, combined with the population geographic distances demonstrated high but non-significant correlations, in other words, the test of significance indicated that the relationship between the populations is independent of geographic distances (linearized $F_{S T}, \mathrm{r}=0.986, \mathrm{p}=0.167$; Nei's genetic distances, $\mathrm{r}=0.998, \mathrm{p}=0.167$ ), a result that indicates the low differentiation between populations.

Table 2. Genetic differentiation $\left(F_{S T}\right)$ between sampled populations of Astrocaryum jauari and between hydrographic basins

\begin{tabular}{|c|c|c|c|}
\hline Populations & Santa Luzia do Buiçuzinho & Nossa Senhora das Graças & Matrinxã \\
\hline Sta. Luzia do Buiçuzinho & - & & \\
\hline Nsa. Sra. das Graças & $0.0588 *$ & - & \\
\hline Matrinxã & $0.0345^{*}$ & $0.0443 *$ & - \\
\hline & \multicolumn{2}{|c|}{ Urucu river } & Solimões river \\
\hline Urucu river & \multicolumn{2}{|c|}{-} & \\
\hline Solimões river & \multicolumn{2}{|c|}{$0.036^{*}$} & - \\
\hline
\end{tabular}

*Significantly different from zero ( $\mathrm{p}<0.017$ after standard Bonferroni correction) between populations and $(\mathrm{p}<0.05)$ between hydrographic basins. 
When the number of genetic homogeneous populations $(K)$ between all plants sampled from the three populations was estimated by Bayesian analysis using Structure software, only one cluster was observed $(K=1, \ln \operatorname{Pr}(X / K)=-1820.9)$ among the accessions studied, indicating that there was no population structure (Pritchard et al. 2000). This result indicates that the three populations are genetically similar. Therefore, data from both Mantel and Structure analyses indicate no structuring between populations, considering the high genetic similarity between these three A. jauari populations in this Amazonian region.

Principal coordinate analysis (PCoA) using Nei's genetic distances, shown in the scatter plot, with both coordinates explaining $45.3 \%$ of the total variation observed (Figure 1B), indicated a separation of members of each population, but also showed that the populations are very similar and this result can be related to the lack of structure found in the Bayesian analysis, suggesting that all of these plants belong to a single population.

\section{DISCUSSION}

By the SSRs primers designed for A. aculeatum that were transferred for use in A. jauari high levels of genetic diversity were detected for this species. The transferability of the primers was possible as a result of the homology between
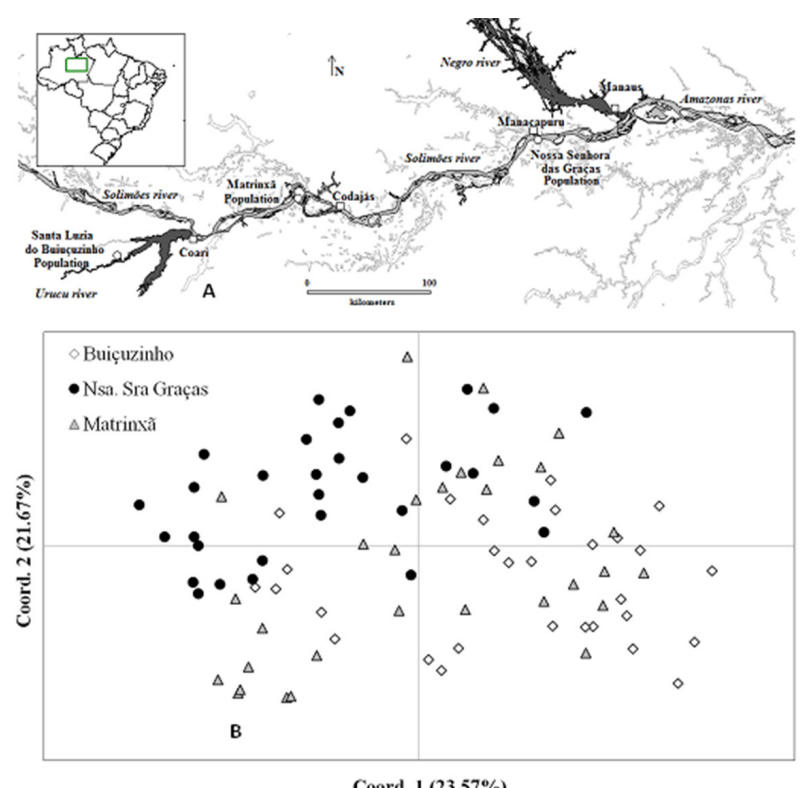

Figure 1. A. Map of the study area in the hydrographic basins of the Urucu and Solimões rivers in Amazonas, Brazil, showing the sampled populations of Astrocaryum jauari and the respective municipalities to which they belong. B. Principal Coordinate Analysis based on nine microsatellites applied to plants of each Astrocaryum jauari population sampled in the hydrographic basins of the Urucu and Solimões rivers in Amazonas, Brazil. the genomes of these two species of the same genus. This homology was also found in the case of SSRs developed for peach-palm (Bactris gasipaes Kunth) that were transferred for use in tucumã palm (Astrocaryum aculeatum) (Ramos et al. 2011), as well as the species cited in the review by Kalia et al. (2011).

High levels of intrapopulation diversity were found in this study. The genetic diversity parameters related to the inbreeding indices presented by $A$. jauari within the populations studied suggest that this species is not endogamous, presenting high levels of heterozigosity. Similar results were obtained in other palm species such as A. mexicanum Liebm. (Eguiarte et al. 1992), Geonoma schottiana Mart. (Silva et al. 2011), Phoenix dactylifera Linn. (Arabnezhad et al. 2012) and Oenocarpus bataua Mart. (Ottewell et al. 2012). This result also suggests that this species has an outcrossing reproductive system, which may be inferred since the application of molecular markers in adult plants and their progenies in species of the same genus detected this type of reproductive strategy (Eguiarte et al. 1992, Ramos et al. 2011). In this study, private alleles were observed for all three populations. The identification of private alleles in populations is useful for application in genetic conservation and can help identify populations that require a special management (Kalinowski 2004). The highest number of private alleles in this study was found in the Nossa Senhora das Graças population, but for better inferences using these results in A. jauari more samples must be screened to observe if there is any variation in the frequency of these alleles.

The three A. jauari populations sampled in the hydrographic basins of the Urucu and Solimões rivers using microsatellite markers presented significant but low genetic differentiation and a lack of genetic structure among populations, suggesting that the samples represent a single population. The genetic structure is highly dependent on the characteristics of the population and the species, as well as the species' ability to disperse its genetic material, the degree to which a population is isolated, its self-incompatibility mechanism and allelic diversity (Leducq et al. 2011).

The currents of the River Urucu flow in the direction of the hydrographic basin of the River Solimões, which leads to believe that any seeds that are not consumed by the fish of the Characidae family, Piaractus brachypomus (pirapitinga) and Colossoma macropomum (tambaqui), may be transported either by fish or the currents of these rivers and deposited on the banks of both rivers, which would hypothetically establish similar populations in these hydrographic basins, with low genetic variability between 
populations through the flow (migration) of plant material. Although the geographic distance between the most distant populations of this study may reach approximately $349 \mathrm{~km}$ along the course of the hydrographic basins, the low genetic differentiation observed between populations supports our hypothesis that plant material is shared between these populations as a result of the dispersal of plant material found in headwaters of the hydrographic basins. Previous studies on Tabebuia ochracea (Moreira et al. 2009) and Phoenix dactylifera (Hamza et al. 2012) provided similar information, reporting low genetic variability between populations. The Mantel test supported this hypothesis, showing that genetic distances between populations are independent of geographical distances.

Principal coordinate analysis indicated high genetic similarity between the three populations in this study. However, small differences between populations were detected in the cluster analysis, showing the greater similarity between the populations from Santa Luzia do Buiuçuzinho and Matrinxã, which formed a slightly different group from the Nossa Senhora das Graças population. This information suggests that the gene flow through seeds can be initiated from the most distant populations and is carried along the course of the rivers, forming similar populations. Barluenga et al. (2011) suggested that seed dispersal is important for the determination of the colonization of new sites and migration between neighboring populations, knowing that the majority of seed species are dispersed by gravity over very short distances. However, the area of seed dispersal may be substantially higher in anemochorous or zoochoric species. When evaluating populations of Silene latifolia Poiret along the hydrographic basin of the river Waal in the Netherlands, these authors showed that most of the genetic variation observed (91\%) could be found within subpopulations and that clusters formed in PCoA indicated low differentiation between subpopulations. Another study on Tabebuia ochracea (Cham.) Standley carried out along the basin of the river São Francisco showed a single cluster for the populations using Bayesian analysis, and that populations separated by distances of over $10 \mathrm{~km}$ and on opposite margins of the river did not present genetic differences, suggesting that this long-distance seed dispersal of this species and that this may involve zoochoric dispersal or physical events associated with the wind and the river (Moreira et al. 2009).

Therefore, taking the results of similar studies into consideration, our investigation shows the high capacity of $A$. jauari for dispersal of the plant material by seeds, indicating high genetic similarity between the three populations in this study for this species. We believe that this dispersal is mainly a result of the strong currents of the rivers in these hydrographic basins and by zoochoric dispersal. The genetic results indicate that the conservation of this species should be carried out mainly in the populations found at the end of the main river, in our case the river Solimões and the Matrinxã and Nossa Senhora das Graças populations, principally the latter, for containing most of the material originating from the headwaters of this river's tributaries. This information about A.jauari is important for the conservation of the species and can be used to determine policies for its management along the hydrographic basins of Amazonia.

\section{ACKNOWLEDGEMENTS}

The authors are indebted to the State of Amazonas Research Foundation (FAPEAM) and National Council for Scientific and Technological Development (CNPq) for scholarships.

\title{
Marcadores microssatélites revelam a diversidade genética e estrutura da palmeira Astrocaryum jauari (Mart.)
}

\begin{abstract}
Resumo - Astrocaryum jauari é uma palmeira não domesticada e explorada de forma extrativista. O objetivo do trabalho foi investigar a organização da diversidade genética e estrutura de três populações de A. jauari. Este estudo foi realizado no estado do Amazonas, entre as cidades de Coari e Manaus. Nove microssatélites foram usados para as análises genéticas. Foi encontrada alta variabilidade genética com um número médio de alelos por loco variando 3,9 a 4,4. As heterozigosidades observadas médias, variando de 0,71 a 0,78, foram maiores que os valores de heterozigosidade esperada. Não foi detectada estrutura genética espacial e foi observado apenas um agrupamento. Os resultados indicam uma possível estratégia de dispersão e sugerem que a conservação desta espécie deve ser realizada principalmente nas populações encontradas no final do rio principal (Solimões), pois contêm a maior parte do material genético proveniente das cabeceiras dos afluentes do presente rio.
\end{abstract}

Palavras-chave: Amazônia, rios Solimões e Urucu, palmeira Jauari, domesticação de palmácea.

\section{REFERENCES}

Albernaz AL, Pressey RL, Costa LRF, Moreira MP, Ramos JF, Assunção

PA and Franciscon CH (2012) Tree species compositional change and conservation implications in the white-water flooded forests of the Brazilian Amazon. Journal of Biogeography 39: 869-883.

Arabnezhad H, Bahar M, Mohammadi HR and Latifian M (2012) Development, characterization and use of microsatellite markers for 
germplasm analysis in date palm (Phoenix dactylifera $\mathrm{L}$.). Scientia Horticulturae 134: 150-156.

Barluenga M, Austerlitz F, Elzinga JA, Teixeira S, Goudet J and Bernasconi G (2011) Fine-scale spatial genetic structure and gene dispersal in Silene latifolia. Heredity 106:13-24.

Doyle JJ and Doyle JL (1990) A rapid total DNA preparation procedure for fresh plant tissue. Focus 12: 13-15.

Eguiarte LE, Perez-Nasser N and Piñero D (1992) Genetic structure, outcrossing rate and heterosis in Astrocaryum mexicanum (tropical palm): implications for evolution and conservation. Heredity 69: 217-228.

Excoffier L and Lischer HEL (2010) Arlequin 3.5: a new series of programs to perform population genetics analyses under Linux and Windows. Molecular Ecology Resources 10: 564-567.

Fraxe TDJP, Witkoski AC and Pereira HDS (2007) Comunidades ribeirinhas amazônicas: memória, ethos e identidade. EDUA, Manaus. 224p.

Frota WM, Sá JAS, Moraes SSB, Rocha BRP and Ismail KAR (2010) Natural gas: the option for a sustainable development and energy in the state of Amazonas. Energy Policy 38: 3830-3836.

Hamza H, Benabderrahim MA, Elbekkay M, Ferdaous G, Triki T and Ferchichi A (2012) Investigation of genetic variation in Tunisian date palm (Phoenix dactylifera L.) cultivars using ISSR marker systems and their relation with fruit characteristics. Turkish Journal of Biology 36: 449-458.

Kahn F and Millán B (1992) Astrocaryum (Palmae) in Amazonia. A preliminary treatment. Bulletin Institute Français d'Étude Andines 21: 459-531.

Kahn F (2008) The genus Astrocaryum (Arecaceae). Revista Peruana de Biología 15: 31-48.

Kalia RK, Rai MK, Kalia S, Singh R and Dhawan AK (2011) Microsatellite markers: an overview of the recent progress in plants. Euphytica 177: 309-334.

Kalinowski ST (2004) Counting alleles with rarefaction: private alleles and hierarchical sampling designs. Conservation Genetics 5: 539-543.

Leducq JB, Llaurens V, Castric V, Saumitou-Laprade P, Hardy OJ and Vekemans X (2011) Effect of balancing selection on spatial genetic structure within populations: theoretical investigations on the selfincompatibility locus and empirical studies in Arabidopsis halleri. Heredity 106: 319-329.

Lewis PO and Zaykin D (2000) Genetic data analysis: computer program for the analysis of allelic data 1.0. Available at $<\mathrm{http}$ :// en.bio-soft.net/dna/gda.html> Accessed on June 20, 2010.

Moreira PA, Fernandes GW and Collevatti RG (2009) Fragmentation and spatial genetic structure in Tabebuia ochracea (Bignoniaceae) a seasonally dry Neotropical tree. Forest Ecology and Management 258: $2690-2695$.
Nei M (1978) Estimation of average heterozygosity and genetic distance from a small number of individuals. Genetics 89: 583-590.

Oosterhout CV, Hutchinson WF, Wills DPM and Shipley P (2004) MicroChecker: software for identifying and correcting genotyping errors in microsatellite data. Molecular Ecology Notes 4: 535-538.

Ottewell K, Grey E, Castillo F and Karubian J (2012) The pollen dispersal kernel and mating system of an insect-pollinated tropical palm, Oenocarpus bataua. Heredity 109: 332-339.

Peakall R and Smouse PE (2012) GenAlEx 6.5: genetic analysis in Excel. Population genetic software for teaching and research - an update. Bioinformatics 28: 2537-2539.

Piedade MTF, Parolin P and Junk WJ (2006) Phenology, fruit production and seed dispersal of Astrocaryum jauari (Arecaceae) in Amazonian black water floodplains. Revista de Biología Tropical 54: 1171-1178.

Piedade MTF, Parolin P and Junk WJ (2003) Estratégias de dispersão, produção de frutos e extrativismo da palmeira Astrocaryum jauari Mart. nos igapós do Rio Negro: implicações para a ictiofauna. Ecología Aplicada 2: 32-40.

Pritchard JK, Stephens M and Donnelly PJ (2000) Inference of population structure using multilocus genotype data. Genetics 155: 945-959.

Ramos SLF, Lopes MTG, Lopes R, Cunha RNV, Macêdo JLV, Contim LAS, Clement CR, Rodrigues DP and Bernardes LG (2011) Determination of the mating system of Tucumã palm using microsatellite markers. Crop Breeding \& Applied Biotechnology 11: 181-185.

Ramos SLF, Macêdo JLV, Lopes MTG, Batista JS, Formiga KM, Silva PP, Saulo-Machado AC and Veasey EA (2012) Microsatellite loci for tucuma of Amazonas (Astrocaryum aculeatum) and amplification in other Arecaceae. American Journal of Botany 99: e508-e510

Rice WR (1989) Analyzing tables of statistical tests. Evolution 43: 223-225.

Schluter UB, Furch B and Joly CA (1993) Physiological and anatomical adaptations by young Astrocaryum jauari Mart. (Arecaceae) in periodically inundated biotopes of Central Amazonia. Biotropica 25: $384-396$

Schuelke M (2000) An economic method for the fluorescent labeling of PCR fragments. Nature Biotechnology 18: 233-234.

Sena JA, Deus LAB, Freitas MAV and Costa L (2012) Extreme events of droughts and floods in Amazonia: 2005 and 2009. Water Resources Management 26: 1665-1676.

Shukla J, Nobre C and Sellers P (1990) Amazon deforestation and climate change. Science 247: 1322-1325.

Silva MS, Vieira FA and Carvalho D (2011) Diversity and genetic structure in natural population of Geonoma schottian Mart (Arecaceae): implications for conservation. Cerne 17: 195-201.

Sioli H (1984) The Amazon and its main affluents: hydrography, morphology of the river courses, and river types. In Sioli H (ed.) The Amazon, limnology and ecology of a mighty tropical river and its 
basin. Junk Publishers, Dordrecht, v. 56, p. 127-165 (Monographiae Biologicae).

Slatkin M (1995) A measure of population subdivision based on microsatellite allele frequencies. Genetics 139: 457-462.

Smouse PR, Long JC and Sokal RR (1986) Multiple regression and correlation extensions of the Mantel test of matrix correspondence. Systematic Zoology 35: 627-632.

Vavrek MJ (2011) Fossil: palaeoecological and palaeogeographical analysis tools. Palaeontologia Electronica 14: 16p. Available at
$<$ http://palaeo-electronica.org/2011_1/238/index.html> Accessed on Jan 15, 2013.

Weir BS and Cockerham CC (1984) Estimating F-statistics for the analysis of population structure. Evolution 38: 1358-1370.

Wright S (1951) The genetic structure of populations. Annals of Eugenics 15: 323-354.

Zambrana NYP, Byg A, Svenning JC, Moraes M, Grandez C and Balslev $\mathrm{H}$ (2007) Diversity of palm uses in the western Amazon. Biodiversity and Conservation 16: 2771-2787. 